\section{Farm Women and Agritourism: Representing a New Rurality}

Wynne Wright* and Alexis Annes**

* Associate Professor

Depts. of Community Sustainability and Sociology

330 B Natural Resources Building

Michigan State University

East Lansing, MI 48824, USA

Tel: (517) 884-1372

Email: wrightwy@anr.msu.edu

**Enseignant Chercheur

UMR LISST-Dynamiques Rurales_-Ecole d'Ingénieurs de Purpan

75 voie du TOEC

BP 57611

31076 Toulouse Cedex 3, France

Tel: (33) 561153086

Email: alexis.annes@purpan.fr

\title{
Abstract
}

This paper examines how farm women represent rurality and agriculture within the context of farm tourism. We draw upon qualitative data analysis of a farm women's agritourism network in southern France centred on sheep milk production for Roquefort cheese. Through the use of choreography, staging, performances, and their bodies, we found that women represent rurality and agriculture in multiple and seemingly contradictory ways. At times they paint portraits of rural life that reproduce human-nature and masculine-feminine binaries affiliated with tradition and cultural heritage. At other times, they choreograph, stage, and perform modernity by accentuating materials, ideals, and roles more accurately articulated as a product of contemporary society. The result is a complex amalgam of agriculture and rural life representations constructed for tourist consumption. We conclude by discussing the opportunities such representations hold for enabling farm women to access cultural influence in agriculture.

Keywords: Agritourism, Cultural heritage, Farm women, France, Representation, Roquefort, Rural, Tradition 
"Juliette threw open the doors to her 125 year old barn and invited us in. She had a big smile and seemed warm. She lives on a 71 ha family farm and she was excited to show us her farm tourism operation. The barn is where she welcomes guests for the tour and 'farm snack'. This beautiful old barn was erected with limestone harvested from the area. There was a massive fireplace opposite the entryway. Antique scythes, wagon wheels, and ox yokes were hung on the walls for art, not cultivation. It was very rustic, traditional ... old world France! We admired it, asked questions about the setting, and complimented her. She is very proud of the renovations and says she wants tourists to appreciate the cultural heritage of Roquefort when they come here. Then we looked up above the fireplace and into the vaulted ceiling to see a large Harley Davidson ${ }^{\circledR}$ Motorcycle flag hanging from the rafters. Oh, no!" (Author's field notes, 2012)

\section{Introduction}

For many, representations of rural France easily evoke picturesque images of a simpler time where bucolic landscapes, dense familial and social bonds, and old world traditions prevail. For the French, aspects of cultural patrimoine and la vieille France (old France) ( $\mathrm{p}$. 280) embody even a more poignant idealisation of rural spaces and livelihoods (Bourdieu 1984; Hervieu and Viard 1996; 2008). Waters (2010) argues that rural traditions characterised by belonging, rootedness, stability and national distinctiveness - along with peasant agriculture, are revered because they offer an antidote from the alienating forces of neo-liberal globalisation. The peasant farmer is frequently heralded as the l'âme de la nation (the soul of the nation), "evoking deep-rooted cultural traditions and implantation in the national territory which define France" (Rogers, 2000, p. 62). The strength of this collective admiration compels Bessière (1998, p. 23) to contend that, in France, the symbolic consumption of the landscape trumps its productive value; "stage-management comes before the productive function in the general public's eye."

Yet, in our first foray into the world of French rural tourism we were met with a Harley Davidson Motorcycle flag, hardly a symbol of la vieille France. Our initial reaction was disappointment because our personal images of the rural idyll (Bunce 1994) were shattered (Bell 2007). Little (1999, p. 440) argues that "the 'rural idyll' has too often "served to detract from the recognition of variety and, indeed, alongside the concept of 'otherness', to 
simplify our understanding of power relations within rural society and of the contestation of the reality and representation of rural culture." For Hinrichs (1996), idealised rural images evoke tradition in ways that omit tension, diversity, and complexity. "Rather than acknowledge conflict, benightedness, or squalor, notions of 'rural tradition' dwell selectively on its most sanitized, beneficent possible features" (1996, p. 263). In this light, Juliette's Harley flag is an invitation to problematise representations of agriculture and rurality within agritourism. ${ }^{1}$ It is a reminder that representations of agriculture and rural life are less homogeneous and more complex than documented, extending an opportunity to explore the ways in which agritourism is organised to symbolically construct rurality in ways that depart from stock idealised or mythical images.

Is it possible Juliette's flag signals the presence of a new rurality? Could agritourism possibly be used to animate roles and identities associated with values and lifestyles emblematic of contemporary identities? Or perhaps farm tourism entrepreneurs interweave tradition, custom and their contemporary multifaceted daily lives to represent to tourists an intricate amalgam of twentieth-first century rurality. We explore these questions in the context of a farm women's agritourism network in southern France called, Réseau de Visites de Ferme (RVF). Using interviews, participant observation, and document analysis, we explore the representations embodied in agritourism as farm women choreograph, stage, and perform agriculture and rurality for the tourist gaze.

Farm tourism packages, accentuates, and commoditises the social and cultural value in farming activity for public consumption (Jackson 1999). The diversification of farms into agritourism has grown considerably in recent years, rising six per cent annually in both North America and Europe from 2002 to 2004 (Choo 2012). Advocates argue that it brings 'fun' to the farm (George and Rilla 2011), yet most contend that the ascendency of agritourism to a position of political and practical relevancy stems from the limits of the 
productionist agrifood model (Brandth and Haugen 2010; 2011; Che et al. 2005; Kneafsey 2000; Marsden and Sonnino 2008; Ploeg 2008; Sonnino 2004). A growing body of research favours farm diversification into agritourism as a remedy for farm family financial stress and risk management (Benjamin 1994; McGehee et al. 2007; Nickerson et al. 2001), rural development (Butler et al. 1998; Hinrichs 1996; Marsden 2003; Neate 1987; Ploeg et al. 2000), nature conservation (Lane 1994), and cultural consumption (such as its amenity value, production of typical products, or heritage protection) (Bessière 1998; Che et al. 2005; Burton and Wilson 2006). Moreover, it is rooted in a contemporary theoretical turn that privileges rural development processes valorising local resources, such as rural people, farmers, and nature, to restore equilibrium to fragmented human and eco-systems (Ploeg et al. 2000). In short, recent literature suggests that agritourism not only fosters economic development, it can also contribute to the maintenance and reinforcement of the rural social fabric, as well as the preservation of the environment. In other words, much of the enthusiasm for agritourism has been justified on the premise that it is prescriptive for the 'sustainable' (economic, social and environmental) development of the countryside (Brandth and Haugen 2011; Marsden and Sonnino 2008; Ploeg and Renting 2004). Given the promise agritourism is claimed to potentially hold for sustainability, we see the nexus of symbolic representation, farm tourism, and gender as fertile terrain for embarking upon an explanatory investigation.

In this paper, we first look to the literature on representations to examine agritourism as a symbolic vehicle of agriculture and rurality (Cloke 1997; 2006; Cloke and Milbourne 1992; Falk and Pinhey 1978; Halfacree 1993; 1995; 1997; 2007; Jones 1995; Mormount, 1990; Pratt 1996). Bessière (1998, p. 20) claims that representation, or "mental perception of the countryside," is often central to rural tourism as tourists reactivate "well-established stereotypes about nature and purity" firmly embedded in their "collective consciousness." Our concern is with the ability of farm women to instrumentally use agritourism to shape 
123 meaning and understanding of agriculture and rural life for tourists drawn from a generation

124 whose knowledge of these domains is limited. Indeed, Cloke (1997, p. 372) writes that "many

125 people are likely to 'know' rural areas more through watching popular television programmes

126 than through personal experience." If accurate, agritourism may be one of the few

127 opportunities urban dwellers have throughout their lives to engage in the rural and to

128 experience agriculture, beyond the realm of eating, making it a pivotal arena for

129 understanding how agriculture and rural life are constructed and performed for uninitiated, yet 130 politically salient audiences.

131 Secondly, a small number of scholars have studied rural representation through a

132 gendered lens, inquiring as to how rural representations depict gender relations, practices, the

133 feminine and masculine body, and the heterosexual norm in rural spaces (Little 2006; Morris

134 and Evans 2013). Most of these studies take media representation as the unit of analysis (Agg

135 and Phillips 1998; Brandth 1995; Liepins 1996; Walter and Wilson 1996). Scholarship has

136 also explored the gendered dimensions of farm tourism, most frequently to explore

137 motivations and characteristics (Babrieri and Mshenga 2008; Getz and Carlson 2000;

138 McGehee et al. 2007), the division of labour in farm tourism (Danes 1998; Dernoi 1991), its

139 ability to increase women's power within the family farm (Bouquet and Winter 1987; Brandth 140 and Haugen 2010; Nilsson 2002) and its impact on women's identity formation (Brandth and

141 Haugen 2011). Yet, there is little empirical research examining how agritourism is used by

142 women to represent rurality to others. Brandth and Haugen (2011) are one exception; they

143 found Norwegian farm women integrating cultural heritage through storytelling, home-

144 cooked local foods, personal dress, and nature-based activities. In addition, food and

145 foodways often play a central role in agritourism representation. Bessière (1998, p. 30) argues

146 that "[h]ighly cultural, culinary heritage is right at the heart of France's rural tourist market." 

entrepreneurs as "actors [who] impose 'their' rurality on others" by choreographing, staging, and performing educational and leisure farm activities. This platform to construct rurality and commodify rural culture for tourists raises important questions that may challenge classical assessments of rural gender dynamics. Is it possible that farm tourism might permit a new

152 form of cultural power farm women have historically been unable to access? The chance to represent agriculture and rural life to tourists gives farm women an unprecedented opportunity to emerge as agricultural authorities, challenging traditional roles held by farm women in scholarship informed by political economics which often cast them as exploited 'farm help' tethered to the farm and a patriarchal system. Brandth et al. (2010) argue that farm women are 157 often able to infuse farm tourism with practical knowledge vital for success. commoditised farm tourism package. By situating this investigation in the everyday (Harding 1991), we find farm women in southern France activating representations of agriculture and

161 rurality that construct a much more complex image of life on the farm. "Their rurality" is 162 one which selectively punctuates tradition interweaving it with social practices and relations 163 endemic of contemporary gender and family roles, while negotiating political-economic realities/uncertainties. In this regard, this paper accentuates the "messiness of rural space" and the inability of farm tourism to map smoothly onto idealised imagery (Cloke 1997, p. 371).

\section{Theoretical Overview}

Theories of social representation of the rural have become a growth industry over the 169 past two decades (Cloke 1997). The deconstructive turn advanced by post-modernism sparked renewed interest in the rural through attention to the socially constructed process which makes

171 it possible (Halfacree 1993; Mormont 1990). The intellectual turn to culture and agency via 
172 phenomenology and the sociology of knowledge (Cloke 1997; Woods 2005), extended to the 173 rural, accentuates the process by which people creatively shape reality through everyday

174 interaction and imaginaries (Bell 2007; Cloke and Milbourne 1992; Falk and Pinhey 1978;

175 Halfacree 1993; 1995; 1997; 2007; Jones, 1995; Pratt, 1996). From this intellectual tradition,

176 rurality arises from "the social production of a set of meanings" attributed to rural spaces, 177 peoples, and practices (Mormont 1990, p. 36).

Foregrounding rural social interaction over spatial or materialist dimensions sets the stage for understanding rurality as a dynamic "social construct and 'rural' becomes a world of social, moral, and cultural values in which rural dwellers participate" (Cloke and Milbourne 1992, p. 360). This approach to the study of rurality has allowed scholars to probe "how

182 practice, behaviour, decision-making and performance are contextualized and influenced by 183 the social and cultural meanings attached to rural places" (Cloke 2006, p. 21), thereby, expanding our capacity to understand the realities of rural people.

Such work foregrounds the micro elements of social life, such as language and social norms, the rural as imaginary or an 'idyll' (Bunce 1994), and the situatedness of everyday experience (Cloke 2006; Frouws 1998; Murdoch and Pratt 1993). Everyday words, symbols and actions become tools in a socialised arsenal to make meaning and represent rural selves to others. Halfacree (1993, p. 29), for example, argues that the rural is best represented through discourse - through the "words and concepts understood and used by people in everyday talk."

191 Through discourse it becomes evident that meanings of rurality do not inhere in the material, 192 but are socio-psychological constructs (Cloke and Milbourne 1992; Frouws 1998; Jones 1995; 193 Pratt 1996; Zografos 2007). Edensor $(2001 ; 2006)$ centralises the role of action in rural representation with the 195 performance metaphor. He argues that rural dwellers 'perform' rurality - or behaviourally 196 manage an impression of themselves as rural people - with their bodies, discursive practices, 
material artefacts, and social environments. In short, rural spaces become a theatre where actors don costumes, stage the setting, and enact performances with culturally appropriate props and scripts. In the tourism context, the goal is to "produce affective, sensual and mediatized experience - within a format of "edutainment'" (Edensor 2006, p. 488). Success depends upon boundary maintenance in which the tourist gaze is directed to discourse and symbolic imagery aligned with the desired representation while being detracted from elements which might undermine this vision. Such was our experience as we stood in Juliette's 125 year old barn perplexed by the contradiction represented by the Harley Davidson flag in the midst of what otherwise appeared as la vieille France.

\section{Gender and Agritourism}

The material and symbolic representations of rural women are less well understood. Investigations into gender and rural representation have typically taken women to be the object of representation, not empowered to represent (Little 2006; Morris and Evans 2013), yet a growing body of scholarship has found that farm women often figure prominently in agritourism initiatives (Barbieri and Mshenga 2008; Brandth and Haugen 2010; Jennings and Stehlik 1999; O’Connor 1995; Oppermann 1995). Studies show that French farm women make a sizeable contribution to farm work, carry a disproportionate share of the household and child care burden, and are more likely than men to manage farm tourism activities (Darque 1988; Giraud and Rémy 2013). For many, women are perceived to be particularly well suited to agritourism given the importance of skills and competencies associated with work women have traditionally performed. Cleaning, cooking, and care work are frequently viewed as an extension of gendered norms into the commercial realm (Brandth and Haugen 2010; 2011; Jennings and Stehlik 1999; McGehee et al. 2007). 
More recently, work has begun to explore the emancipatory potential within agritourism. Brandth and Haugen (2010, p. 425) argue that "engaging in farm tourism implies a change that not only demands new skills and competencies but may also influence the conditions under which gender relationships, power, and identities are enacted.” Studies reveal a range of consequences, from relatively static or no change in women's position to significant improvements (Brandth and Haugen 2010; Evans and Ilbery 1996; Cánoves et al. 2004). These studies have been primarily concerned with individual, household, or farm-level changes such as those which increase women's status, decision-making, or income within the household or farm or studies that posit a change to individual identity (Brandth and Haugen 2010). Work is needed which considers the macro implications of women as cultural authorities. ability to provide women with a platform for exercising cultural authority - for transgressing normative gender boundaries and constructing a professional and contemporary identity

235 imbued with contradictions and complexities. Rather than confine women to the backstage of 236 cooking, cleaning, and caretaking, some forms of agritourism move women to the front stage 237 of the farm unit. Educational or pedagogical farm tourism, for example, may provide a venue 238 for recoding farm women as knowledgeable and authoritative. Farm tourism allows women 239 the chance to model professional expertise and transmit practical knowledge historically 240 associated with men. Farm women may disseminate complex biological, economic, political 241 and social processes and practices essential for daily agricultural functioning; demonstrate the 242 workings of sophisticated technology, unpack convoluted international agricultural policy and 243 economic formulas, explain conservation strategies and environmental policy, animate 244 cultural and geographic histories, and showcase technical exhibits. All this, while answering 245 an array of questions from “what do sheep eat?' to 'why do farmers receive government 
246 subsidies?'. Lest we forget, they demonstrate this knowledge and skill all the while cooking 247 for and feeding tourists.

We explore the ways farm tourism affords women visibility and how they use this role

249 to represent agriculture and rural life. Our focus is on the content of these representations,

250 with particular attention to the ways in which rural traditions and contemporary livelihoods

251 are symbolically constructed for tourists.

\section{Background}

Réseau de Visites de Ferme (RVF) is an agritourism network of farm women located in Aveyron, France devoted to disseminating knowledge of sheep farming. Aveyron is one of the 96 political departments of France and belongs to the southern Midi-Pyrenees region. It is

257 a landscape of breath-taking scenery and geological diversity composed of massive and craggy mountains, deep gorges, serene meadows, and numerous waterways. The high limestone plateau known as the Grands Causses is made up of a series of underground caves. Part of the region is located in the Massif Central. Rural character has lingered much longer in this area than in other regions of the country. It is commonly described as la France profonde - the heartland - a region of unspoiled rural France. Some add the adjective "backward" to depict the area and its people. Saugeres (2002, p. 376) contends that "the inhabitants of the

264 region have developed a strong sense of a distinct identity, a sense of nostalgia for the 265 traditional ways of life of the peasantry, alongside an inferiority complex of being 266 'backward', and the desire to be as modern and developed as in most areas of France." Agriculture remains central to the economic portfolio of Aveyron, employing 15-20 268 per cent of the labour force (Frayssignes, 2011). Its origins lie in the small scale agro-pastoral 269 system where peasants largely produced cereals and herded sheep, but industrialisation and 270 concentration began to take hold in the early twentieth century. Modern transportation, along 
271 with the development of a cash economy, made possible highly specialised sheep farming for

272 the purpose of supplying milk to the Roquefort cheese market. "Between 1960 and 1980, the

273 production system became much more intensive with the amalgamation and modernisation of

274 farms, intensive forage crop growing, animal breeding programmes and an increase in the

275 volume of milk produced" (Quétier et al. 2005, p. 173). By 2000, 95 per cent of all

276 agricultural income in the region was derived from sheep farming (Frayssignes 2011), with

277 sheep producers numbering 2,458.

278 Roquefort is a blue cheese made of raw sheep milk derived primarily from the

279 Lacaune breed of sheep which are fed a diet of 75 per cent pasture and regional fodder.

280 Roquefort production is an intensive and industrial process. Milk is stored on farm in bulk

281 tanks and trucks arrive daily to retrieve it and deliver it to a local cheese dairy for processing.

282 In 1960, there were 460 small cheese dairies across the region, but today there are seven. One 283 firm (Société) represents 70 per cent of the market.

Once the milk arrives at the dairy, the milk will be heated and rennet and penicillium

285 roqueforti will be added to ignite lactic fermentation. It is then cut to separate the curds and

286 whey, moulded into "loaves" or large wheels, and allowed to drain for two days. Next, the

287 cheese is salted and pricked to "enable the carbon dioxide generated during the fermentation

288 process to escape and thereby encourage the development of the penicillium roqueforti"

289 during the ripening process (Confédération Générale de Roquefort N.d. p. 47). Finally, the

290 cheese wheel is marked with information regarding herd origins and manufacturing date to

291 facilitate traceability and then sent for ripening to the limestone caves located beneath its

292 namesake village - Roquefort-sur-Soulzon. Natural ventilation in the cellars produces

293 constant humidity and temperature providing a conducive microclimate for activating the

294 penicillium roqueforti which creates the blue-green veins. Once ripe, women "cabin workers" 
fold each wheel in tinfoil and prepare it for the market. In 2001, 3,000 tons of Roquefort was exported to more than 90 countries (Frayssignes 2011).

298 bucolic landscapes and the preservation of longstanding cultural traditions, yet this brief 299 overview affirms that the production of Roquefort is a highly industrialised process. Cheese 300 is manufactured via a regulated process informed by "the strictest scientific conditions" 301 (Confédération Générale de Roquefort N.d., p. 49) and marketed to an international consumer base who demand a standardised product. For many, quality cheese production conjures up images of small scale artisanal production, but in the case of Roquefort the more accurate representation is an industrial laboratory setting where white lab-coat-wearing workers inject microscopic fungi into uniform cheese wheels to ignite a biological process. holds, that "[i]f Roquefort sneezes, all the region catches a cold" (Frayssignes 2011, p. 5).

311 Contrólée (AOC), ${ }^{2}$ are granted legal protection as a form of collective intellectual property.

312 Roquefort was the first cheese in France to receive this official status in 1925 and received

313 similar protective status from the European Union in 1996 when it was registered as a

314 Protected Designation of Origin (PDO). Since 1930, the red ewe label that graces each wheel

315 of cheese has guaranteed to the consumer authenticity and quality, but for producers, AOC

316 standards "strongly affect the way farms are managed" (Quetier et al. 2005, p. 172). AOC

317 standards can also influence the ways farm women represent rural life and agriculture through 318 agritourism. 
Frayssignes (2011) argues that the link to rural development, although significant, is not a priority of Roquefort supply chain actors, especially, the cheese processors. Although

321 the caves draw in approximately 200,000 visitors a year for tours, the only other tourism 322 presence is the RVF which was launched in 1993 by two of its current members. Its origins 323 are rooted in a request from the Confédération Générale de Roquefort - the regulatory 324 association made up of milk producers and processors - that milk producers open up their 325 farms to tourists to share the milk production process and its rich cultural heritage. Members of the RVF welcome tourists to their family farms to provide a goûters à la ferme, or 'farm snack'. The farm snack is a popular form of farmstead hospitality in France (Bessière 1998), and, in this case, is accompanied by a guided educational tour where the host disseminates knowledge of milk production as well as sharing the cultural heritage of sheep

330 farming and the natural amenities of the area that make Roquefort distinctive and globally 331 recognized. Overall, each member of the RVF offers the same type of services: first the 332 guided educational tour, then the 'farm snack'. Likewise, three types of farm snacks are 333 offered by all members, from a basic option including Roquefort cheese and local wine to a 334 more elaborate one including Roquefort cheese, local wine, and traditional deserts. In 335 addition, the general outline of the guided tour is similar from one member to another (they 336 share the same educational material). Offering a homogeneous package is essential to the 337 members of RVF - especially to the founding members, in order to be clearly identified. 338 However, some differences exist depending on the characteristics of each farm and on each 339 member's personal interest and desire to develop one particular aspect of the business. The 340 RVF functions in some ways like a woman's auxiliary that serves to support and bolster 341 often via the realm of culture - the cheese industry. At the end of the farm tour, guests are 342 often directed to visit the caves in Roquefort-sur-Soulzon. 
344 members, but currently only four participate, ranging in ages from 45 to 62 . Three of the four

345 members are also full-time farmers ${ }^{3}$ working with either their husband or son, while the fourth

346 member identified herself as a farm employee. Regardless of official status, their primary role

347 on the farm is to milk the sheep twice daily. Three are also responsible for the management of

348 the farm records, and some also engage in other farm activities, such as poultry and

349 gardening.

Methods

The research design consisted of three components: 1) semi-structured interviews; 2) participant observation; and, 3) document analysis. We interviewed each of the four members of the Network as well as one former member. Each of the five interviews were conducted at their farm and ranged in length from $1 \frac{1 / 2}{-}-4$ hours. Interviews were conducted in French, tape-recorded, and later partially transcribed and translated. Both authors were present for the interviews as was a language interpreter. Interviews consisted of approximately 40 open and closed-ended questions covering subjects such as farm history, farm and agritourism organisation and interaction, motivations, gender dynamics, and future visions. In each case, researchers were also given a guided tour of the farm and facilities. assumed the role of tourist on two separate occasions and took part in an actual farm visit

363 along with other guests. The visit allowed us to observe first-hand the interaction of the host

364 with the guest, to hear the script, and to experience the visit as a tourist. Perhaps most importantly, it allowed us to engage with other tourists, to watch their reactions and learn what information appeared to resonate with them. 
368 advertising brochure and their website. Network members were also able to provide us with a

369 number of newspaper articles profiling their work which turned out to be useful for

370 understanding the evolution of the group.

371 We have given each member a pseudonym in an effort to disassociate her comments

372 from her identity. Given the small sample size it is not possible to determine if these findings

373 represent all farm women agritourism entrepreneurs. We offer these data to ignite further

374 scrutiny of this phenomenon, providing evidence for theorising about the ways rural and

375 agriculture are represented by women as rural restructuring is performed in ways which blur

376 conventional production and consumption boundaries.

\section{Representing Rurality}

In this section, we analyse how Network members use their role as agritourism

entrepreneurs to represent agriculture and rural life. We examine women's agritourism work in regards to the organisation of the initiative, its staging, performance, and the discourse they use to animate rural life and agriculture. In this section we will show how RVF Network members reproduce nostalgic imagery associated with an agrarian past along with traditional

384 social relations. Yet, tradition is not the only commodity on offer. Farm women also represent 385 agriculture and rural life in ways that animate modernity. First, we turn to a discussion of traditional representation where we find women activating custom and convention in three ways, through: 1) marketing, organising, and narrating the farm tour around AOC sanctioned

388 production practices; 2) designing and staging the farm tour; and, 3) their bodies via 389 performances as food provider and caretaker. 
393 process of organising the farm tour and delimiting the numerous possibilities farm tourism

394 could take. In this regard, the organisation of the tourism experience is prescribed, in part, by 395 Roquefort itself and the AOC certification process. Bowen and DeMaster (2011) argue that 396 the setting of quality assurance standards is an inherently political project whereby some 397 practices are included, and others omitted, from protection, thereby shaping and constraining 398 what is protected or permitted. In essence, such standards are an attempt to bound (Edensor 399 2001) history, place, and culture. For agritourism, this means that the codification of quality assurance standards in the 401 AOC legal framework not only establishes the parameters of production practices, but it also establishes the parameters of any activity which seeks to communicate the nature of production processes, such as farm tourism. Any effort to transmit the production practices of

404 sheep farming will indirectly follow the production guidelines set by Roquefort AOC. This 405 enhances the likelihood of homogeneity of tourist experience among members in the 406 Network, but distinguishes it from other non-Roquefort agritourism initiatives. The AOC quality assurance standards prescribe the basic protocol for the production 408 process, foregrounding tradition, cultural heritage, and the distinctive properties of the natural 409 landscape. We can see women reproduce these guidelines in the way they market the 410 Network, organise the farm tour, and narrate the milk production process. The advertising 411 brochure, for example, may be the first encounter guests have that begins the work of 412 representing tradition. At the origin of Roquefort cheese, before the maturing of the cheese in the caves, there is country, farms, sheep farmers, ewes and their milk... There is an entire world which 
is quite often unknown. Animated by the desire to share their passion for their job, four 'agricultrices' [farm women] invite you to discover their job in all its richness/intensity. They welcome you to their place, in Roquefort country, in the heart of the typical landscapes and the traditional architectural heritage of the Parc Naturel Regional of the Grands Causses. They introduce you to the world of their farm, they tell you its story and they speak about their lives shaped by the seasons (author transcription, RVF brochure, 2012).

This representation constructs sheep producers as both traditional and distinctive.

424 of formality by evoking a down-home character associated with the hospitality and charm ascribed to rural people. It accentuates social solidarity and the expressive forms of rationality associated with "passion", not the instrumentality of science and industrial food

427 production methods. It also calls on the rural idyll by situating farms within the natural 428 landscape, furthered by a nod to seasonality. Imagery such as "cheese", "caves", "Roquefort country", "traditional architectural heritage" and the "Grands Causses" also help to brand 430 them as unique. An aura of mystique is punctuated throughout when referencing the 431 "unknown" "world" of their region and work. Such framing segregates farm women and their 432 "world" of sheep farming from tourists, and, in this way, perpetuates their image as different 433 or "other" (Hall 1997; Little 1999). Weightman (1987, p. 230) contends that "the tour 434 brochure directs expectations, influences perceptions, and thereby provides a preconceived 435 landscape for the tourist to discover." This suggests that what tourists may be primed to 436 witness is a cultural reproduction of the rural/urban binary at work. Hosts may foreground 437 that which differentiates rural and urban dwellers (nature, culture, heritage, patrimoine) 438 instead of that which bonds them (modernity, capitalism, etc.). Therefore, as suggested by 439 Holloway in examining the British context (2004), by emphasizing differences between rural 
440

441

and urban dwellers, hosts may be underlining tourists' preconceived ideas of rural life and reinforcing rural/urban cleavages where common values, identities, and aspirations are otherwise masked.

The advertising brochure and the website illuminate tradition and distinctiveness and when guests arrive they enter a scene designed and staged to reinforce this imagery. From the script that farm women use to narrate the farm tour, to the architecture tourists observe, to the final snack they consume, tradition and cultural heritage are enrolled to represent life on a working sheep farm. Juliette describes how she begins to orient guests upon first arrival. I tell people we are different. Our region is really rural, really agricultural, with people with strong characters. They are proud people of their roots and their heritage.

Juliette's orientation is to follow the lead of the brochure and position her region and people as distinctive, or "other", and, at the same time, illuminate the importance of cultural heritage. Apolline uses her farm tour to achieve similar distinctive objectives.

When people arrive, first I speak about the region, its specificities. From there, we speak about the park of the Grands Causses, then of the production area in which we need to be located to produce milk to be used in the making of Roquefort. Next, I focus on the farm with its specificities, how it works, how it's organised, where it's located, its natural environment, its buildings, its architectural heritage.

Apolline's narrative punctuates the symbolic imagery associated with the unique features of cultural heritage and tradition by enrolling AOC standards, the farm, nature, and architecture as props to authenticate the representation. Perhaps the most significant prop is the barn.

One of the criteria for RVF membership is that each woman must have a suitable 'old' barn in which to welcome tourists and provide the snack. Perhaps no image resurrects rurality 
463 in the same way as agricultural barns constructed of materials typical of the nineteenth

464 century, such as honey-colored stone harvested from the local terrain, with massive hand-cut 465 tongue and groove wooden beams. These buildings began their life housing Lacaune sheep 466 around 150-200 years ago, but became obsolete in the 1960s-1970s when farmers adopted 467 mechanical milking machines. Today, preservation of these barns is perceived by the French 468 as part of their patrimoine, or cultural heritage. renovated it for their agritourism business. From a former place of production, the old sheep 471 barns are now repurposed spaces for urban consumption (Hinrichs 1996; Potter and Tilzey 472 2005). In reclaiming this traditional architecture and enrolling them as props in agritourism 473 staging, the women participate in cultural heritage protection and the transmission of 474 patrimoine. As Agathe said, "[b]arns like ours give authenticity, terroir, a sense of history, 475 everything. If cheese tasting takes place in a regular room, it's not the same thing."

477 fortifies the image of la vieille France. Each barn is staged with several long roughly hewn 478 farm tables and benches or mismatched chairs. Old features were preserved where possible, 479 such as a fireplace or sheep milking stanchions. Antique farm implements line the stone walls 480 not to celebrate progress as Holloway (2004) found in his study of British agricultural shows. 481 The rustic motif transports tourists to an agrarian past, all be it, one sanitised of the animals, 482 with attendant smells and sounds emblematic of authentic animal housing. Lastly, we found women constructing an image of rurality as tradition with their 484 bodies. The performances they play as food providers and caretakers are an extension of 485 typical roles associated with women in the home, into the realm of farm tourism (Pini 2004). 486 The women take it upon themselves to welcome the guests, guide the tour, write and deliver 
the script, as well as cook and serve the snack. The wine and cheese are purchased locally, but the desserts are prepared by each woman in her home kitchen. Foods are presented on artisanal stoneware, both prepared and presented to further the yesteryear image through home cooking and craft production. By assuming the role as cook, and presenting foods in a traditional manner, the farm woman preform a traditional gendered division of labour - for the purpose of commodification (Brandth and Haugen 2010), while at the same time representing notions of food purity and wholesomeness (Ilbery and Kneafsey 2000).

This part of the paper has shown that tradition, cultural heritage, and distinctiveness 495 play key roles in the farm women's representations of rurality. They accomplish this in their marketing, organisation, and narration of the farm tour, the designing and staging of the farm tour, and through their bodies as they perform customary roles ascribed to rural women. This supports previous research that has found farm tourism to be "inextricably intertwined with

499 historical, political, and cultural processes" (Pritchard and Morgan 2001, p. 168). Whether it 500 is the AOC certification standards that politically prescribe production parameters, or the 501 cultural artefacts that confer resource availability, farm women's representations reproduce a 502 binary division that may portray them and their livelihood as yesterday's people. This 503 "marking of difference" (Hall 1997, p. 232), or "othering", may, indeed, be the commodity 504 that tourist's demand, yet today's image, may be tomorrow's obstacle. Such images run the 505 risk of fostering stereotypes of complex sub-cultures and places as simple, hardy and self506 sufficient and not in need of responsive rural development policies. It may also further the 507 gulf between rural and urban populations if it is not replaced or buttressed with social and 508 cultural imagery that communicates authenticity of experience and contemporary realities. Indeed, we discovered that traditional representations of rural life are not immutable.

510 Just as often as tradition was constructed, so too was the diversity and complexity of 
511 contemporary life. We now turn to a discussion of how farm women use agritourism in ways 512 that confound tradition, heritage and distinctiveness.

\section{Recoding Roquefort}

514 Representations of agriculture and rurality by farm women accentuate classic imagery

515 associated with agrarian traditions, however, such representations were also buttressed by a

516 dynamism indicative of modernity. Beck (1992) tells us that under reflexive modernity,

517 individuals have more agency to construct their lives in a multiplicity of ways. Just as we saw

518 women instrumentally exploiting tradition for commodification, we also observed hosts

519 resisting convention, and infusing diversity and the prosaic elements of everyday farm and

520 family life into their agritourism operation to recode agriculture and rurality with a modern

521 orientation. In this section, we discuss how RVF members turn the tables on tradition in three

522 ways, through: 1) marketing, organising, and narrating the farm tour to accentuate knowledge

523 and professionalism; 2) performing everyday, lived experiences; and 3) with their bodies, via

524 identity management.

First, the very visibility of farm women is far from a minor addition to the rural story.

526 Women's place on the farm has historically been read as largely exploited and invisible

527 (Alston 1995; Brandth 1998; Sachs 1983; Shortall 1999), assigned to the backstage of family

528 farming where they play a secondary role as farm helper, but rarely viewed as a farmer in

529 their own right. Saugeres (2002) has argued in the case of France that women are rarely

530 viewed as 'farmers' because the occupation is constructed as a masculine endeavour. The role

531 as agritourism entrepreneur not only makes them visible, (Barbieri and Mshenga 2008;

532 Brandth and Haugen 2010; Jennings and Stehlik 1999; O’Connor 1995; Oppermann 1995),

533 but allows them to craft a professional image and demonstrate specialised knowledge and

534 authority. Farm tourism also permits women to cultivate both an interest and income 
generating activity of their own and diversify their range of activities atypical of traditional

536 farm women's lives.

The representation of farm women as professionals begins once again in the marketing

538 domain as the brochure emphasizes farm tourism as not a way of life or hobby, but a "job".

539 “Animated by the desire to share their passion for their job, four agricultrices' [farm women]

540 invite you to discover their job in all its richness/intensity." Historically, farm women were

541 referred to as paysan or fermière. Around the mid-century - during rapid adoption of

542 industrial farming methods, the modern label of agriculteur began to be applied to farmers

543 who embraced production for commercial markets with intensive and scientific methods. At

544 the same time, a woman similarly engaged in commercial agriculture began to be referred to

545 as an agricultrice. By invoking the label agricultrices, members of the Network align

546 themselves with this professional status.

In the early days of the Network, members worked closely with the Grands Causses

548 Regional Park which trained them to host farm tourism activities. Jocelyne recalls being

549 excited by their insistence on professionalism. They warned, "be careful, your job is being a

550 farmer, people don't want to come to a museum. People want to come to your workplace.”

551 She took this advice to heart and structured a well-organised tour along with a narrative that

552 recounted for guests the highly technical aspects of the production process along with

553 economic and political realities of modern day sheep farming.

554 The importance of professionalism was reinforced by each member, but more

555 noticeable among the younger members. Some made significant investments to construct a

556 professional agritourism business. Juliette left her husband, two sons, and the family farm for

557 four months to attend cheese school in the north of France. This was very unpopular with her

558 husband and in-laws, who feared neighbours might gossip about her absence from the home 
for such a period. She insisted that proper training was crucial, in part, because her dream is to expand the operation one day to produce her own cheese.

Professionalism is also accompanied by the assertion of independence and autonomy.

562 Women resisted traditional farm roles where they were ascribed to the role of 'farm help', and 563 advocated for having their own "activity." "A little something of my own on the farm" was

564 the primary driver for entrepreneurialism among each woman. As Apolline put it, "when you 565 arrive on your in-laws farm, you need to create your own space.” For Jocelyne, once newly 566 married, her husband preferred she assume traditional mothering and homemaking roles. When I arrived here we were three generations under one roof and my mother-in- law was doing my husband's wash...He would tell me, 'for God's sake, why can't you stay home?' I told him no, I would be bored... It is important for me to have relationships. I thought that starting this activity, welcoming people, would help me recreate these relationships and give me something of my own.

572 Perhaps the most forceful in her demand for autonomy was Apolline who agreed to "work on 573 the farm and in agritourism only if [she] was in charge to the same degree as [her] husband 574 and brother-in-law... [They] took the decision to go into agritourism together.” In this way, 575 their desire for their own individual income-generating farm activity, is in line with other 576 research that has found autonomy to be a driving motivational factor in the decision to farm 577 more generally (see Mooney, 1986). Each of the members saw themselves as the primary agritourism entrepreneur and the 579 husband as secondary. This relocates women in positions of authority and demotes men to the 580 role of helper. Even though Apolline claimed her husband was an equal partner and regularly 581 involved, she described his role as being primarily confined to the backstage where he was 582 responsible for maintenance and infrastructure. His regularly occurring visible role was to 
583 provide entertainment for the guests; when she slips out to get the snack he performs a short 584 sheepdog demonstration. Such a division of labour situates women in positions of authority 585 and furthers the separation with tradition, and at the same time, it also recasts men in 586 agriculture. According to Charlotte, she and her husband also embarked upon agritourism primarily as a joint venture. They share in leading the tours even though there are strong rural norms that go against such activity for men.

My husband likes leading the tours but he says that most farmers around here would not, rural areas are patriarchal where men drive tractors and women milk. Other farmers would make fun of him if they knew he hosted visitors on the farm...I don't consider welcoming guests as feminine, my husband prepares flowers and jam, but

These cases suggest that women's professionalism in agritourism casts men in secondary roles. Now men play the part of 'helper' and assist in uncompensated work that resides in the sphere of cultural reproduction.

The dependence on science and technology is also seen to challenge the dominance of tradition. Farm women choreograph and narrate the tour in ways that demonstrate a broad knowledge base in a range of complicated social, biological, and technological processes. Just

601 as the barns can be enrolled to mimic tradition, tours are also choreographed to highlight 602 state-of-the-art buildings equipped with the latest technology, such as modern milking 603 machines and hay driers. Charlotte de-emphasizes tradition when she explains why the old 604 stone barn can no longer serve the needs of a modern sheep farm. Jocelyne incorporates 605 modernity when she recounts the long programme of selective breeding that has doubled milk 606 production over the last 20 years. 
Women commonly reported that the guests were unprepared to see such 'modern' technology and production practices. Agathe said, "when they arrive they are surprised to see

609 the way we work, the buildings, the milking room. They see the milking room tiled and they 610 say 'it's a real lab that you have." Apolline's overview shows how she disseminates modern 611 production practices. I start it in the area where we dry hay where there is enough space and were I set up

Each of the women reported showcasing production practices designed to impress the tourist with state-of-the-art methods and the upmost regard for adherence to quality assurance standards. As guests are led through the barns they are exposed to stainless steel bulk tanks that store milk at precise temperatures, equipment used to test daily for pathogens in the milk, and machines that can milk 500-600 sheep in an hour. They walk by posters that detail complicated nutritional formulas that vary by the season; they are instructed on the

631 importance of lactation cycles, genetic improvements, and artificial insemination. Apolline 
incorporates a PowerPoint presentation that explains the origins of AOC regulations and how

633 production standards assure cheese quality in partnership with numerous actors across the

634 Roquefort supply chain. Agathe adds fluency in international agricultural policy when she

635 informs tourists about the role of farm subsidies. "People ask about the subsidies a lot...so I

636 explain that subsidies are here to compensate farmers because consumer prices have not gone

637 up for many years. They think it is charity; they have no idea what a farmer earns and they

638 have a lot of misconceptions. I tell them the truth."

The litany of skills necessary to make this performance credible is not insignificant.

640 Their comfort with chemistry, biology, and technology animates the know-how that gives

641 AOC products their distinctive shared practices, yet with a modern veneer. Quality assurance

642 standards may be time and space bound, but the traditional know-how required to produce

643 Roquefort is accomplished with contemporary skills, competencies, and science and

644 technology applications. Such fluency with cutting-edge knowledge and techniques helps to

645 recode women from disposable farm helpers to authorities with a wide range of skills and 646 professional acumen.

Some are disillusioned with this representation of modern sheep farming, according to

648 Charlotte. "All these people have a romantic vision of farm life. Their image of the farmer is

649 from the media and is old fashioned and not realistic. Some are disappointed to see it is not

650 rural enough. Some feel cheated when they see modern hygiene equipment." The introduction

651 of the modern, through "hygiene equipment" or other technologies or practices suggests a

652 shattering of the rural idyll and reinforces the gulf that segregates rural producers from urban

653 tourists.

Network members also root their tourist activity in the present, making sure the tourist

655 leaves with an accurate understanding of life on a modern sheep farm. Women frequently 
find, intentionally or unintentionally, that the exigencies of life are often on stage for tourists view. Charlotte makes an effort to ensure guests have a "direct experience with everything. I want them to touch, see, smell everything. I try to have them understand that we work

659 here...We clean up but it should not be too perfect...it is a working farm." Jocelyne 660 punctuates the multiple demands modern women have on their shoulders by communicating 661 the multi-tasking she does. When they call for an appointment I tell them "that they cannot come 30 minutes late because otherwise I would be late to complete my other chores like the milking."

Each of the women also reported having their tours interrupted by family members from time to time. Children barge in with a question, husbands stop by to greet the guests, neighbours pop in unexpected, phones ring, and oven timers buzz forcing women to briefly excuse themselves to tend to lunch preparations. Such disruptions bring to light the numerous activities that require women's attention and, at the same time, communicate a blurring of

669 productive and reproductive spheres. An awareness of the difficulties women face in balancing farm, tourism and household obligations begins to shatter images of traditional

671 divisions of labour where women and men are confined to prescribed roles. bodies as they dress to look the part of a real farmer. Some agritourism operators find it useful to wear culturally specific attire to evoke some desired sentiment (Brandth and Haugen

675 2010), but the women in the Network eschew traditional dress in favour of modelling a

676 twentieth-first century representation. Apolline is often told by guests that they did not expect 677 to "meet a farm woman looking like [her]. Maybe they were expecting someone older. 678 Usually they are also surprised to see a house with a lawn, a farm house well-ordered. They 679 tell me that they were not expecting a modern, dynamic woman like me." For some members, 680 dress can be an important way to defensively manage an impression of themselves. Looking 
the part of a modern farm woman can also be a tool to combat the negative stereotypes often directed toward rural people. Juliette's fashion choices seem to be aimed at both these ends. Sometimes the kids tell me they want to see the fermière [farmwoman]. I tell them I am the fermière. It is true that in kid's books the fermière is more likely to appear with a scarf holding a basket. I think there is a difference for some people between what

In a similar defensive vein, Agathe adds that she wants them to know that she is not "bagnard," or a convict, that she is not chained to the farm toiling endlessly, but enjoys the same activities as urban residents, including family vacations. "Before coming, they have a lot of clichés in their mind...Parisians still see us with clogs and boots."

Saugeres (2002) argues that Aveyron residents are typically believed to suffer from a sense of inferiority in comparison with other French citizens and often strive to prove that

697 they are just as modern as others. Whether such forms of identity management described

698 above are enacted to counter the stereotype of themselves as 'backward farmers' specifically,

699 or the more general 'Aveyron resident', may be impossible to disentangle. They are,

700 however, evidence for how women use their bodies to transgress traditional symbolic

701 boundaries and plant the seeds for a new rural and agricultural imagery.

\section{Conclusion}

French agritourism entrepreneurs represent farm tourism in ways that interweave

704 tradition, cultural heritage, and distinctiveness with contemporary knowledge, expertise, 
economic and political realities, and symbols. Imagery of an agrarian past is commonplace,

706 but an asymmetrical interpretation of the representations farm women create within

707 agritourism is also present. Performances, staging, and organisation, intentionally and

708 unintentionally, also construct agriculture and rural life as modern, dynamic, and

709 multifaceted. Custom and tradition collide with rationality and individuality creating a

710 paradox. The result is a representation for tourists that complicates the la vieille France

711 imagery of agriculture and rural life. As Juliet affirms, "[w]e show them that agriculture is

712 evolving, that it's modern, but that at the same time, there is patrimoine, a gastronomical

713 heritage as well as an architectural one."

Whereas Bowen and DeMaster (2011) see similar heritage-based initiatives which

715 become institutionalised through policy as freezing culture in time and place, we found in

716 agritourism - also prescribed by heritage-based regulations - a degree of dynamism. We found

717 the Network members showing and telling a story that aims to strike some semblance of a

718 balance to convey the complexity and totality of the rural experience, both intentionally and

719 unintentionally. Edensor (2006, p. 485) argues that rural performances are both self-

720 conscious or deliberate action and habitual at the same time, "an interweaving of conscious

721 and unaware modalities, part of the flow of ongoing existence."

AOC guidelines that accentuates tradition, cultural heritage and distinctiveness, yet

724 regulations have not frozen production practices in place. They may have been set by custom,

725 but they are increasingly accomplished with modern, industrial implements and techniques in

726 an effort to respond to changing local and global economies (Frayssignes 2011). This

727 orientation allows Network members to blur the boundaries of tradition and modernity as they

728 demonstrate their recasting of cultural heritage with contemporary tools, such as milking

729 equipment, industrial processors, EU subsidies, and international trade laws. As women are 
the embodiment of authority in the tourist experience, they are also able to challenge

731

732

733

734 conventional imagery of the farmer (the embodied male farmer) and make a feminised imprint on agriculture. In this way, AOC regulations become malleable, contouring agriculture or rural representation, without concretising it.

In addition to animating AOC standards accomplished with modern means, Network members also infuse the complexities of everyday life in the performance as they enact daily life in view of tourists. Because their home is the setting, the lived experience of sheep producers is often on view, allowing guests a front seat to the backstage of contemporary rural life. Hard working, unassuming rural people bound together in dense kinships ties, so the stock idealised image goes, become demanding, over-programmed, busy professionals with a wide range of skills, knowledge, and responsibilities - a heterogeneous mix whose lifestyles reverberate diversity. Bodies are used to further manage an impression of themselves as modern, both to show how they adapt to socio-economic or political realities, as well as creatively infusing a sense of self into the encounter. This desire of the farm women to imprint on the tourist experience stands in stark contrast to the invisibility of their mothers and grandmothers.

Through their participation in RVF, women challenge classical assessments of rural gender dynamics by moving from a position of 'farm help' to one of 'agricultural authority'. Literature suggests that for decades farm women had been confined to the backstage, exploited and invisible, in charge of the household and required to contribute to male-defined farm activities (Sachs, 1983; Saugeres, 2002). Agritourism may provide women an opportunity to move to the front stage of the farm. In fact, hosting visitors on the farm might afford women the opportunity to move from a position of societal invisibility (Sachs, 1983) to assume roles that hold promise for significant influence. 

challenge dominant representations of women as "incomplete farmers" (Saugeres, 2002) by preforming the role of 'agricultural authority.' This role might permit a new form of cultural

757 power farm women have historically been unable to access. In the context of this activity,

758 they are able to demonstrate to the public their agricultural knowledge and skills. Their power 759 to represent, stage and perform rurality allows them to build a bridge between rural and urban 760 populations that seem increasingly polarised. However, future research is needed to explore

761 how tourists interpret such imagery, as well as the long term implications of such

762 representations on urban values and political sensitivity to rural issues. In short, it is

763 questionable to what extent representations that fragment social relations and enlarge gulfs

764 between rural and urban populations enhance shared meaning and understanding.

Lastly, agritourism may also be fertile ground for women's empowerment within the context of the family farm. However, as previously suggested by the literature (Brandth and Haugen, 2010), whether these new opportunities empower women or change on-farm power relations remains unsettled. If our research participants appear as agricultural authorities in the eyes of the public, the extent to which this role challenges a traditional distribution of power between men and women requires further exploration. Further research should explore how agritourism initiatives can empower farm women on the farm and within the household.

\section{Acknowledgements}

775 The authors would like to thank Meredith Redlin for insightful comments on this manuscript. Earlier versions of this paper were presented at the Centre International d'Études Supérieures en Sciences Agronomiques (SupAgro), Montpellier, the 2013 INRA conference "New Forms of Agricultures: Ordinary practices, public debate and social critique" (Dijon, France), South 
Dakota State University, Dept. of Sociology and Rural Studies, and the 2013 Rural

780 Sociological Society annual meeting. We are indebted to the feedback of the audience

781 members which helped us fine tune our analysis. Funding for this research was supported by

782 the Institut National Polytechnique of Toulouse, France, through a Soutien Mobilité

783 Internationale grant and Michigan AgBioResearch.

\section{Endnotes}

${ }^{1}$.In this paper, we use farm tourism and agritourism interchangeably

${ }^{2}$.The officially defined AOC Roquefort region is not synonymous with Aveyron. Today milk is sourced from two regions, the Midi-Pyrenees and Languedoc-Roussillon and six departments: Aude, Aveyron, Gard, Hérault, Lozére, and Tarn.

${ }^{3}$.In 1962, the Groupement Agricole d'Exploitation en Commun (GAEC) agricultural framework was created to allow two individuals to legally enter into a business partnership, sharing the work and the benefits. The two contractees were considered as co-operators. GAEC contracts were seen as a path toward agricultural modernisation, a mechanism for improving productivity by increasing farm size. The earliest GAEC contracts could be entered only by parents and children (typically, father/sons). Modifications allowed spouses (husband/wives) to enter a GAEC contract in 2004.

\section{References}

Agg, J. and M. Phillips (1998) Neglected gender dimensions of rural social restructuring, Pp. 252-279 in P. Boyle and K. Halfacree, eds., Migration issues in rural areas (London: Wiley)

Alston, M. (1995) Women on the land: the hidden heart of rural Australia. (Kensington: University of New South Wales Press)

Barberi, C., and P.M. Mshenga (2008) The role of the firm and owner characteristics on the performance of agritourism farms. Sociologia Ruralis 48 (2) pp. 166-183

Beck, U. (1992) Risk society: towards a new modernity. (London: Sage)

Bell, M.M. (2007) The two-ness of rural life and the ends of rural scholarship. Journal of Rural Studies 23 (4) pp. 402-415

Bell, M.M., S.E. Loyd and C. Vatovec (2010) Activating the countryside: rural power, the power of the rural and the making of rural politics. Sociologia Ruralis 50 (3) pp. $205-224$

Benjamin, C. (1994) The growing importance of diversification activities for French farm households. Journal of Rural Studies 10 (4) pp. 331-342 
Bessière, J. (1998) Local development and heritage: traditional food and cuisine as tourist attractions in rural areas. Sociologia Ruralis 38 (1) pp. 19-34

Bouquet, M. and M. Winter (1987) Who from their labour rest? (Aldershot: Avebury)

Bourdieu, P. (1984) Distinction. (Cambridge, MA: Harvard University Press)

Bowen S., and K. DeMaster (2011) New rural livelihoods or museums of production? Quality food initiatives in practice. Journal of Rural Studies 27 (1) pp. 73-82

Brandth, B. (1995) Rural masculinity in transition: gender images in tractor advertisements. Journal of Rural Studies 11 (2) pp. 123-133

Brandth, B. (2002) Gender identity in European family farming: a literature review. Sociologia Ruralis 42 (3) pp.181-200

Brandth, B. and M. S. Haugen (2011) Farm diversification into tourism - implications for social identity? Journal of Rural Studies 27 pp. 35-44

Brandth, D. and M.S. Haugen (2010) Doing farm tourism: The intertwining practices of gender and work. Signs: Journal of Women in Culture and Society 35 (2) pp. 426-446

Brandth, B., M.S. Haugen, A. Kroken (2010) Farm tourism: a question of gender and competence? Paper presented at the Nordic rural futures: pressures and possibilities, Uppsala, Norway. 3-5 May

Brunori, G. and A. Rossi (2007) Differentiating countryside: social representations and governance patterns in rural areas with high social density: the case of Chianti, Italy. Journal of Rural Studies 23 pp. 183-205

Bunce, M. (1994) The countryside ideal. (London: Routledge)

Buller, H. (2000) Re-creating rural territories: LEADER in France. Sociologia Ruralis 40 (2) pp. 190-199

Burton, R.J.F. and G.A. Wilson (2006) Injecting social psychology theory into conceptualization of agricultural agency: Towards a post-productivist farmer self-identity? Journal of Rural Studies 22 (1) pp. 95-115

Butler, R., C.M. Hall and J. M. Jenkins (1998) Tourism and recreation in rural areas. (Chichester: Wiley)

Cánoves, G., M. Villarino, G. K. Priestley, and A. Blanco (2004) Rural tourism in Spain: an analysis of recent evolution. Geoforum 35 (6) pp. 755-69

Che, D., G. Veeck, and A. Veeck (2005) Agriculture and the selling of local food products, farming, and rural America tradition to maintain family farming heritage. Pp 109-121 in S. Essex, A.W. Gilg, R.B. Yarwood, eds., Rural Change and Sustainability: Agriculture and Environment and Community. (Wallingford: CAB International) 
Choo, H. (2012) Agritourism: development and research. Journal of Tourism Research and Hospitality 1 (2) pp. 1-2

Cloke, P. (1997) 'Country backwater to virtual village'?: rural studies and 'the cultural turn.’ Journal of Rural Studies 13 pp. 367-75

Cloke, P. (2006) Conceptualizing rurality. Pp 18-28 in P. Cloke, T. Marsden, and P.H. Mooney, eds., The Handbook of Rural Studies. (London: Sage)

Cloke, P. and P. Milbourne (1992) Deprivation and lifestyle in rural Wales: rurality and the cultural dimension. Journal of Rural Studies 8 (4) pp. 71-76

Confédération Générale des Producteurs De Lait Brebis Industriels De Roquefort. N.d. Roquefort: Garanti D’Origine et de Qualité. (Millau: Graphi Imprimeur)

Danes, S. (1998) Farm Family Business. (Minneapolis, MN: University of Minnesota Extension Service)

Darque, M. B. (1988) The division of labor and decision-making in farming couples: power and negotiation. Sociologia Ruralis 28 (4) pp. 272-292

Dernoi, L. (1991) About rural and farm tourism. Tourism Recreation Research 16 (1) pp. 3-6

Edensor, T. (2006) Performing rurality. Pp. 355-364 in P. Cloke, T. Marsden and P.H. Mooney eds., The handbook of rural studies. (London: Sage)

Edensor, T. (2001) Performing tourism, staging tourism: (re)producing tourist space and practice. Tourist Studies 1 (1) pp. 59-81

Evans, N. and B. Ilbery (1996) Exploring the influence of farm-based pluriactivity on gender relations in capitalist agriculture. Sociologia Ruralis 36 (1) pp. 74-92

Falk, W. and T. Pinhey (1978) Making sense of the concept rural and doing rural sociology: an interpretive perspective. Rural Sociology 43 (4) pp. 547-558

Frayssignes, J. (2011) System IV: Roquefort Cheese (France). Pp.177-183 in E. Barham and B. Sylvander, eds., Labels of origin for food: local development, global recognition. (Wallingford: CAB International)

Frouws, J. (1998) The contested redefinition of the countryside: an analysis of rural discourses in the Netherlands. Sociologia Ruralis 38 (1) pp. 54-68

George, H. and E. Rilla (2011) Agritourism and nature tourism in California. (Davis: University of California Press)

Getz, D. and J. Carlson (2000) Characteristics and goals of family and owner-operated business in the rural tourism industry and hospitality sectors. Tourism Management 21 (6) pp. 547-560 
Giraud, C. and J. Rémy (2013) Division conjugale du travail et légitimité professionnelle : le cas des activités de diversification en France. Travail, Genre et Société 30 pp. 157-174.

Halfacree, K.H. (1993) Locality and social representation: space, discourse and alternative definitions of the rural. Journal of Rural Studies 9 (1) pp. 23-37

Halfacree, K.H. (1995) Talking about rurality: social representations of the rural as expressed by research in six English parishes. Journal of Rural Studies 11 (1) pp. 120.

Halfacree, K.H. (1997) Contrasting roles for the post-productionist countryside: a postmodern perspective on counterurbanisation. Pp -in P. Cloke, J. Little eds. Contested countryside cultures: otherness, marginalization and rurality. (London: Routledge)

Halfacree, K.H. (2007) Trial by space for a 'radical rural': introducing alternative localities, representations and lives. Journal of Rural Studies 23 pp. 125-141

Hall, S. (1997) The spectacle of the "other". Pp 223-290 in S. Hall ed., Representation: cultural representation and signifying practice. (London: Sage)

Harding, S. (1991) Whose science, whose knowledge: thinking from women's lives. (Ithaca: Cornell University Press)

Haugen, M.S. (1998) The gendering of farming: the case of Norway. European Journal of Women's Studies 5 (2) pp. 133-153

Hervieu, B. and J. Viard (2008) L'archipel paysan, la fin de la République agricole. Editions de l'Aube, La Tout d'Aigues.

Hervieu, B. and J. Vivard (1996) Au bonheur des campagnes (et des provinces). (Marseille: Editions de l' Aube)

Hinrichs, C.C. (1996) Consuming images: making and marketing Vermont as distinctive rural place. Pp. 259-278 in P. Vandergeest and E.M. DuPuis eds., Creating the countryside: the politics of rural and environmental discourse. (Philadelphia: Temple University Press)

Holloway, L. (2004) Showing and telling farming: agricultural shows and re-imaging British agriculture. Journal of Rural Studies 20 (3) pp. 319-330

Ilbery, B, and M. Kneafsey (2000) Producer constructions of quality in regional specialty food production: a case study from south west England. Journal of Rural Studies 16 (2) pp. 217-230

Jackson, P. (1999) Commodity cultures: the traffic in things. Transactions of the Institute of British Geographers NS 24 (1) pp. 95-108

Jennings, G. and D. Stehlik. (1999) The innovators are women: the development of farm tourism in Central Queensland, Australia. Pp. 84-98 in Conference 
proceedings of the 1999 annual ISTTE conference. One world, one community, one mission. (Vancouver, Canada)

Jonasson, M. (2012) Co-producing and co-performing attractive rural living in popular media. Rural Society 22 (1) pp. 17-30

Jones, O. (1995) Lay discourses of the rural: developments and implications for rural studies. Journal of Rural Studies 11 (1) pp. 35-50

Kneafsey, M. (2000) Tourism, place identities and social relations in the European rural periphery. European Urban and Regional Studies 7 (1) pp. 35-50

Lane, B. (1994) Sustainable rural tourism strategies: a tool for development and conservation. Pp 102-111 in W. Bramwell and B. Lane eds., Rural tourism and sustainable development: proceedings of the second international school on rural development (Clevedon: Channel View)

Leipins, R. (1996) Reading agricultural power: media as sites and processes in the construction of meaning. New Zealand Geographer 32 pp. 3-10

Little, J.K. (2006) Gender and sexuality in rural communities. Pp. 365-378 in P. Cloke, T. Marsden, and P.H. Mooney eds., Handbook of Rural Studies. (London: Sage)

Little, J. (1999) Otherness, representation and the cultural construction of rurality. Progress in Human Geography 22 (3) pp. 437-442

Marsden, T. (2003) The condition of rural sustainability. (Assen: Van Gorcum)

Marsden, T. and R. Sonnino. (2008). Rural development and the regional state: denying multifunctional agriculture in the UK. Journal of Rural Studies 24 (4) pp. 422-431

McGehee, N.G., Kim, K and G.R. Jennings (2007) Gender and motivation for agritourism entrepreneurship. Tourism Management 28 (1) pp. 280-289

Mooney, P.H. (1986) My own boss: class, rationality and the family farm. (Boulder, CO: Westview)

Mormont, M. (1990) 'Who is rural?' or, how to be rural: towards a sociology of the rural. Pp. 21-44 in T. Marsden, P. Lowe, and S. Whatmore eds., Rural restructuring. (London: Fulton)

Morris, C and N. Evans (2001) 'Cheese makers are always women': gendered representations of farm life in the agricultural press. Gender, Place \& Culture: A Journal of Feminist Geography 8(4) pp. 375-390

Murdoch, J. and A. C. Pratt (1993) Rural studies: modernism, post-modernism and the 'post-rural'. Journal of Rural Studies 9 (4) pp. 411-427

Neate, S. (1987) The role of tourism in sustaining farm structure and communities on the Isles of Scilly. Pp. 9-12 in M. Bouquet and M. Winter eds, Who from their labors rest? Conflict and practice in rural tourism. (Avebury: Aldershot) 
Nilsson, P. Á. (2002) Staying on farms: an ideological background. Annals of Tourism Research 29 (1) pp. 7-24

Nickerson, N.P., R. Black, and S.F. McCool (2001) Agritourism motivations behind farm/ranch business diversification. Journal of Travel Research 40 (1) pp. 19-26

O’Connor, P. (1995) Tourism and development in Ballyhoura: women's business? Economic and Social Review 26 (4) pp. 369-401

Oppermann, M. (1995) Holidays on the farm: a case study of German hosts and guests. Journal of Travel Research 34 (1) pp. 63-67

Pini, B. (2004) Gender and farming in the information economy. Australian Journal of Communication 31 (2) pp. 135-48

Ploeg, J.D.v.d. (2008) The new peasantries: struggles for autonomy and sustainability in an era of empire and globalization. (London: Earthscan)

Ploeg, J.D.v.d. and H. Renting (2004) Behind the redux: a rejoiner to David Goodman. Sociologia Ruralis 44 (2) pp. 233-242

Ploeg, J.D.v.d, H. Renting, G. Brunori, K. Knickel, J. Mannion, et al. (2000) Rural development: from practices and policies towards theory. Sociologia Ruralis 40 (4) pp. 391-408

Potter, C. and M. Tilzey. (2005) Agricultural policy discourse in the European postfordist transition: neoliberalism, neomercantilism and multifunctionality. Progress in Human Geography 29 (3) pp. 1-20

Pratt, A. C. (1996) Discourses of rurality: loose talk or social struggle? Journal of Rural Studies 12 (1) pp. 69-78

Pritchard, A. and N. J. Morgan. (2001) Culture, identity, and tourism representation: marketing Cymru or Wales? Tourism Management 22 pp. 167-179

Pritchard, A. and N. J. Morgan (2000) Constructing tourism landscapes: gender, sexuality, and space. Tourism Geographies 2 (2) pp. 115-139

Quetier, F., P. Marty, J.Lepart (2005) Farmers management strategies and land use in an agropastoral landscape: roquefort cheese production rules as a driver of change. Agricultural Systems 84 pp. 171-193

Rogers, S.C. (2000) Farming visions: agriculture in French culture. French Politics, Culture and Society 18 (1) pp. 50-70

Sachs, C. (1983) The invisible farmers: women in agricultural production. (Totowa, NJ: Rowman and Allanheld)

Saugeres, L. (2002) The cultural representation of the farming landscape: masculinity, power and nature. Journal of Rural Studies 18 (4) pp. 373-384 
Shortall, A. (1992) Power analysis and farm wives: an empirical study of the power relationships affecting women on Irish farms. Sociologia Ruralis 32 (4) pp. 431451

Shortall, S. (1999) Women and farming: property and power. (London: Macmillan)

Sonnino, R. (2004) 'For a 'piece of bread'?: interpreting sustainable development through agritourism in southern Tuscany. Sociologia Ruralis 44 (3) pp. 285-300

Walter, G. and S. Wilson (1996) Silent partners: women in farm magazines success stories, 1934-1991. Rural Sociology 61 (2) pp. 227-248

Waters, S. (2010) Globalization, the Confederation Paysanne, and symbolic power. French Politics, Culture \& Society 28(2) pp. 96-117

Weightman, B.A. (1987) Third world tour landscapes. Annals of Tourism Research 14 (2) pp. 227-239

Wilson, G. (2001) From productivism to post-productivism ... and back again?: exploring the (un)changed natural and mental landscapes of European agriculture. Transactions, Institutes of British Geographers 26 (1) pp. 77-102

Woods, M. (2008) Social movements and rural politics. Journal of Rural Studies 24 (2) pp. $129-137$

Woods, M. (2005) Rural geography: processes, responses and experiences in rural restructuring (London: Sage)

Zografos, C. (2007) Rurality discourses and the role of the social enterprise in regenerating rural Scotland. Journal of Rural Studies 23 (1) pp. 38-51 